\title{
Potential Application of Urea and NPK 15:15:15 Fertilizers as Biostimulants in the Bioremediation of Domestic Wastewater
}

\author{
Andrew N. Amenaghawon", Peter A. Asegame, Kessington O. Obahiagbon \\ Department of Chemical Engineering, University of Benin, Benin City, Nigeria \\ *Corresponding author: andrew.amenaghawon@uniben.edu
}

Received July 30, 2013; Revised September 02, 2013; Accepted September, 05, 2013

\begin{abstract}
The role of urea and NPK 15:15:15 fertilisers as biostimulants of microbes in the bioremediation of domestic wastewater was investigated in this study. Five samples of domestic wastewater supplemented with 10, 20, 40, 60 and $80 \mathrm{~g} / \mathrm{L}$ of urea, NPK as well as a combination of both fertilisers and the control were monitored for bioremediation. The indicating parameters such as $\mathrm{pH}$, Biochemical Oxygen Demand (BOD), and Dissolved Oxygen (DO) over a period of 5 weeks were used. The results obtained showed that there was a BOD reduction of 86.62, 85.24 and $86.85 \%$ for wastewater treated with urea, NPK and a combination of both respectively. Stimulation by the fertilisers improved the DO level by 76, 75 and $77.8 \%$ respectively for wastewater treated with urea, NPK and a combination of both respectively. Generally, the best results were obtained when both fertilisers were used together. The final values of $\mathrm{pH}$, BOD and DO fell within the values of 6-9, $30 \mathrm{mg} / \mathrm{L}$ and $2 \mathrm{mg} / \mathrm{L}$ set by the Federal Environmental Protection Agency (FEPA). The results obtained indicate the effective use of urea and NPK fertilisers in stimulating the activity of microbes for bioremediation in wastewater.
\end{abstract}

Keywords: bioremediation, domestic wastewater, urea, NPK, Biochemical Oxygen Demand, dissolved oxygen

Cite This Article: Andrew N. Amenaghawon, Peter A. Asegame, and Kessington O. Obahiagbon, "Potential Application of Urea and NPK 15:15:15 Fertilizers as Biostimulants in the Bioremediation of Domestic Wastewater." American Journal of Environmental Protection 1, no. 4 (2013): 91-95. doi: 10.12691/env-1-4-3.

\section{Introduction}

The growing population of urban centers in Nigeria and other developing countries poses a serious threat to the environment due to the extensive generation of huge amounts of wastewater [1,2]. These wastewaters are typically effluents from a host of activities ranging from industrial, municipal and agricultural to domestic [3,4,5]. There are thousands of restaurants and fast-food shops in Nigeria and they use over a million tons of water everyday. The direct discharge of wastewater generated from these restaurants and shops down the drain without treatment represents a huge environmental burden. The major effect of the improper disposal of untreated wastewater (especially those containing nitrates and phosphates) into natural water bodies is eutrophication $[1,6,7,8]$. In addition, the release of untreated wastewater leads to the accumulation of toxic products in the receiving water bodies with potentially serious consequences on the immediate ecological environment $[2,9,10]$.

Treatment of wastewater is currently carried out by a host of physical and chemical methods which are often costly and inefficient [10,11]. For the past decade, a lot of attention has been given to the use of bioremediation as a means of treating wastewater and other effluents in a cost effective way. It is seen as an effective and environmentally friendly treatment option for wastewater [10]. Bioremediation involves the breakdown of complex organic molecules through biostimulation and bioaugmentation into simpler substances such as fatty acids, carbon dioxide and water [12]. Previous works done on the bioremediation of contaminated wastewater focused on natural attenuation, biostimulation and bioaugmentation with varying degrees of success recorded. Obahiagbon and Aluyor [13] studied the potential use of inorganic nutrient (sodium nitrate and sodium nitrite) for the biostimulation of Aspergillus niger for the bioremediation of petroleum hydrocarbon polluted water. Kim et al. [14] reported enhanced bioremediation rates of crude oil contaminated sand as a result of addition of inorganic nutrients. Agbor et al [12] applied cocoa pod husk and plantain peels for the biostimulation of microbes during the biodegradation of crude oil polluted soil. Chikere et al. [15] and Ebere et al. [16] reported on the effectiveness of poultry droppings in enhancing the degradation of crude oil polluted soil in Southeastern Nigeria. One common feature of these studies is that the addition of nutrients is necessary to enhance bioremediation [17].

Hence the aim of this study was to examine the potential applicability of inorganic fertilizers urea and NPK 15:15:15 for the biostimulation of indigenous microorganisms for the purpose of treating domestic wastewater. 


\section{Materials and Methods}

\subsection{Sample Collection and Preparation}

The domestic wastewater used for this study was obtained from fast food outlet at the city centre in Benin City, Edo State, Nigeria. Wastewater samples were collected in plastic containers previously cleaned by washing in non-ionic detergent, rinsed with tap water and later soaked in $10 \% \mathrm{HNO}_{3}$ for 24 hours and finally rinsed with deionised water prior to usage. The wastewater was collected at source to prevent any form of foreign contamination not associated with the process from which it was obtained. The wastewater was dispensed in $500 \mathrm{~mL}$ quantities into six sets of $1000 \mathrm{~mL}$ beakers. Beakers in each experimental set were then supplemented with different levels (10, 20, 40, 60 and $80 \mathrm{~g} / \mathrm{L})$ of nutrient sources urea and NPK 15:15:15 fertilizer as well as a combination of both in the ratio 1:1. A controlled experiment which did not contain any nutrient supplements was set up to serve as comparison between biostimulation and natural attenuation (bioremediation) to determine the effectiveness of the nutrient supplements in treating domestic wastewater.

\subsection{Analyses}

The physicochemical properties of the wastewater were monitored in the course of the remediation process. The following parameters; $\mathrm{pH}, \mathrm{BOD}$, and DO were monitored weekly for a period of 5 weeks. Sampling was done on day zero (before biostimulation) and subsequently at intervals of seven days (one week).

The $\mathrm{pH}$ of the samples was measured using an electronic $\mathrm{pH}$ meter (Fisher Accruement $\mathrm{pH}$ meter). The $\mathrm{BOD}$ and DO were determined following the standard methods of APHA [18].

\section{Results and Discussion}

\subsection{Variation of $\mathbf{p H}$ with Bioremediation Time}

The physicochemical parameters of wastewater are important in that they indicate the degree of biodegradation [12]. They are used to assess whether or not it is safe to discharge treated wastewater into naturally occurring water bodies [19]. Figure 1,Figure 2, and Figure 3 show the variation of the $\mathrm{pH}$ of the wastewater with time in the course of bioremediation. The indigenous microbes responsible for the bioremediation process were biostimulated with urea fertiliser, NPK 15:15:15 fertiliser and a combination of both as shown in Figure 1, Figure 2 and Figure 3 respectively. The Figures represent 3-D plots showing the effect of the concentration of biostimulant (fertilisers) and remediation time on the $\mathrm{pH}$ of the wastewater as it undergoes bioremediation. The general trend observed indicates that the $\mathrm{pH}$ of the wastewater increased with increase in bioremediation time. The initial $\mathrm{pH}$ of the sample was 5.9 indicating slight acidity. This might be as a result of the type of the type of food substances prepared in the fast food outlets which are mainly vegetables, carbohydrates, proteins as well as fats and oils and consequently these will require an acid detergent for cleaning. Acid detergents are used mainly for protein, mineral and vegetable deposit removal and typically contain phosphoric acid [20]. It can be observed from Figure 1 that at the start of bioremediation, the $\mathrm{pH}$ of the wastewater increased with increase in the concentration of urea fertiliser.

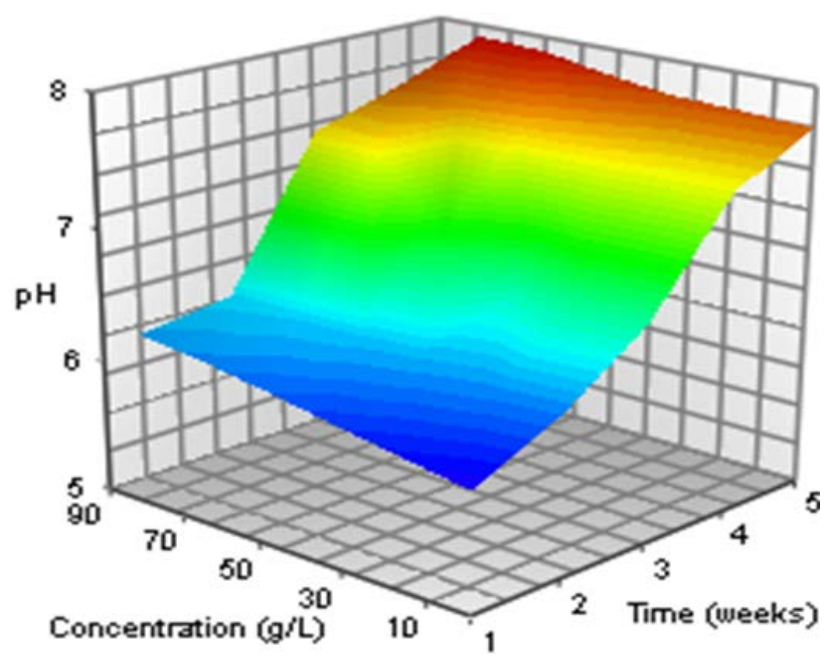

Figure 1. Variation of $\mathrm{pH}$ with time for wastewater remediated with urea fertilizer

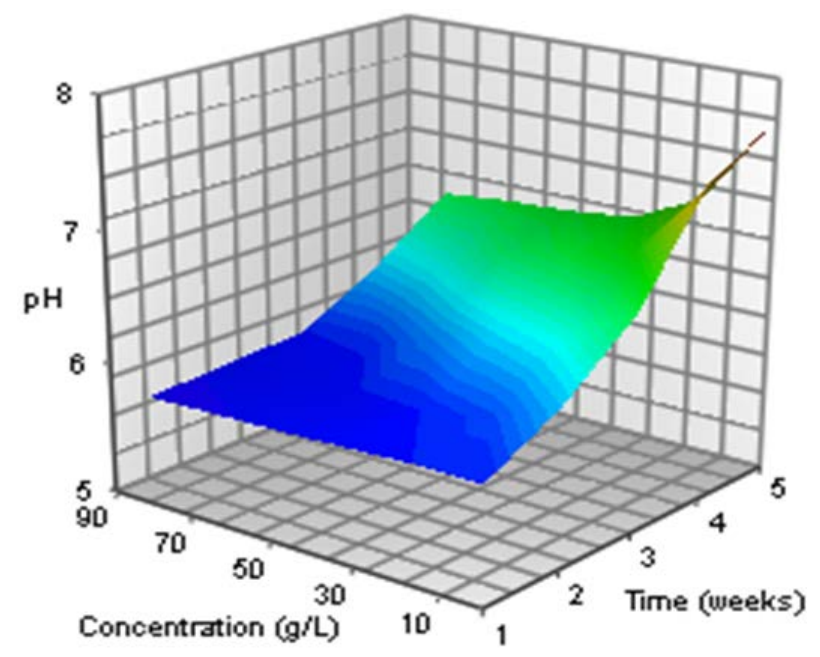

Figure 2. Variation of $\mathrm{pH}$ with time for wastewater remediated with NPK fertilizer

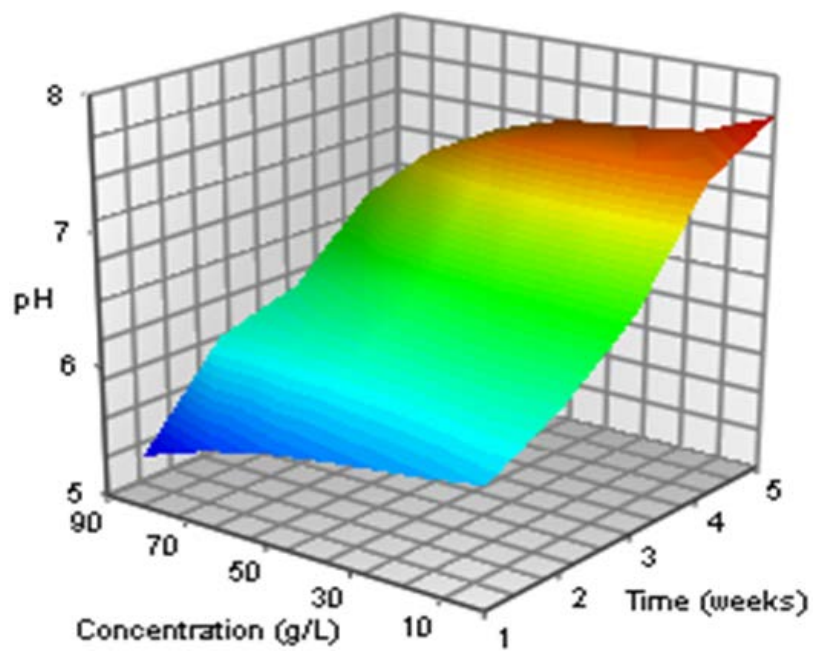

Figure 3. Variation of $\mathrm{pH}$ with time for wastewater remediated with both urea and NPK fertilizer 
The same trend was also observed at the end of the remediation process. This may be as a result of the fact that urea is basic in solution and action. However a different trend was observed for the wastewater remediated with NPK fertiliser as shown in Figure 2. The trend observed indicate that the $\mathrm{pH}$ decreased with increase in the concentration of NPK fertiliser indicating that NPK might be slightly acidic in action. For the wastewater remediated with both urea and NPK fertiliser (Figure 3), a trend similar to that of Figure 2 was observed i.e. the $\mathrm{pH}$ decreased with increase in the concentration of fertiliser. The $\mathrm{pH}$ values recorded for all the treatment methods were within the range (6-9) set by the Federal Environmental Protection Agency [21]. The $\mathrm{pH}$ is a dynamic parameter in an aquatic ecological environment as it changes with the physical and chemical properties of the water body over time [22].

\subsection{Variation of BOD with Bioremediation Time}

The BOD is a largely accepted water quality indicating parameter. It is a measure of the degree of pollution of a given water body [22]. The profiles of the BOD of the wastewater at various concentrations of urea, NPK and a combination of both fertilisers are shown in Figure 4, Figure 5, and Figure 6 respectively. The general trend observed for all three Figures indicate that the BOD of the wastewater decreased with increase in the concentration of the stimulants both at the start and at the end of bioremediation. It can also be observed that the BOD of the samples decreased with time in the course of bioremediation. At a concentration of $0 \mathrm{~g} / \mathrm{L}$ (no biostimulant added) there was still an observable reduction (though not significant) in the $\mathrm{BOD}$ of the wastewater with time. The reduction in BOD could be attributed to the activities of the indigenous microbes present in the wastewater which converts the contaminants into less toxic substances such as $\mathrm{CO}_{2}, \mathrm{H}_{2} \mathrm{O}$ and many intermediates like organic acids, lipids, esters, complex alcohols and microbial proteins in form of enzymes [13]. Higher reductions in BOD were recorded when stimulants were added indicating that the biodegrading ability of the indigenous microorganism had been enhanced. The BOD was reduced from 120.34 to $16.10 \mathrm{mg} / \mathrm{L}, 120.3417 .76$ $\mathrm{mg} / \mathrm{L}$ and 120.34 to $15.83 \mathrm{mg} / \mathrm{L}$ corresponding to 86.62 , 85.24 and $86.85 \%$ removal efficiencies for wastewater treated with urea, NPK and a combination of both respectively as shown in Figure 4, Figure 5, and Figure 6. Obahiagbon and Aluyor, [13] reported enhance bioremediation levels when crude oil contaminated water was supplemented with nitrates. Similar results were reported by Satyawali and Balakrishnan, [23] for the treatment of wastewater from molasses-based alcohol distilleries. The better performance observed for urea relative to NPK can be explained by noting that biodegrading microorganisms need oxygen, carbon and hydrogen to function optimally. These are present in urea fertiliser and not in NPK fertiliser. It also stands to reason that the best result was obtained when both fertilisers were combined. This is because the medium then contained all necessary nutrient needed by the microbes as shown in Figure 6. These values fell below the maximum value of $30 \mathrm{mg} / \mathrm{L}$ stipulated by FEPA.

\subsection{Variation of DO with Bioremediation Time}

Figure 7,Figure 8, and Figure 9 show the variation of the dissolved oxygen (DO) content of the wastewater with time at various concentrations of fertiliser. The trend evident from the Figures indicate that there was a direct relationship between the DO and the concentration of fertilisers used suggesting that increasing the dose of fertilisers enhanced the bioremediation ability of the indigenous microbes in the wastewater.

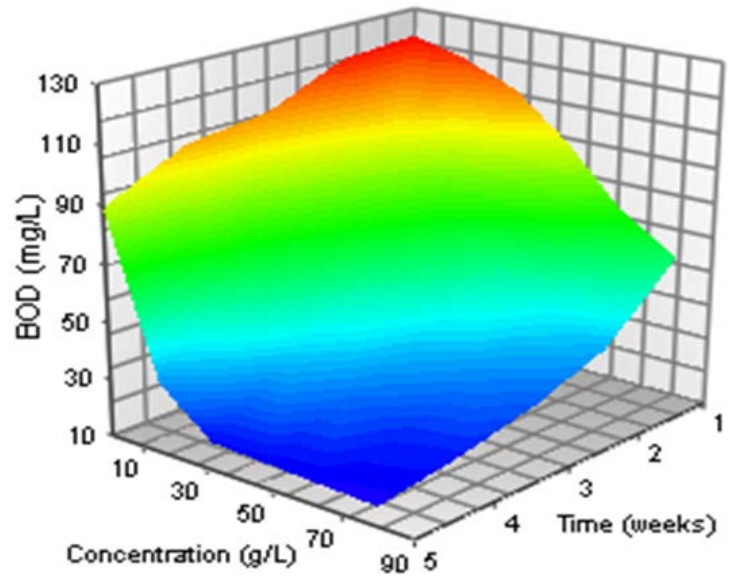

Figure 4. Variation of BOD with time for wastewater remediated with urea fertilizer

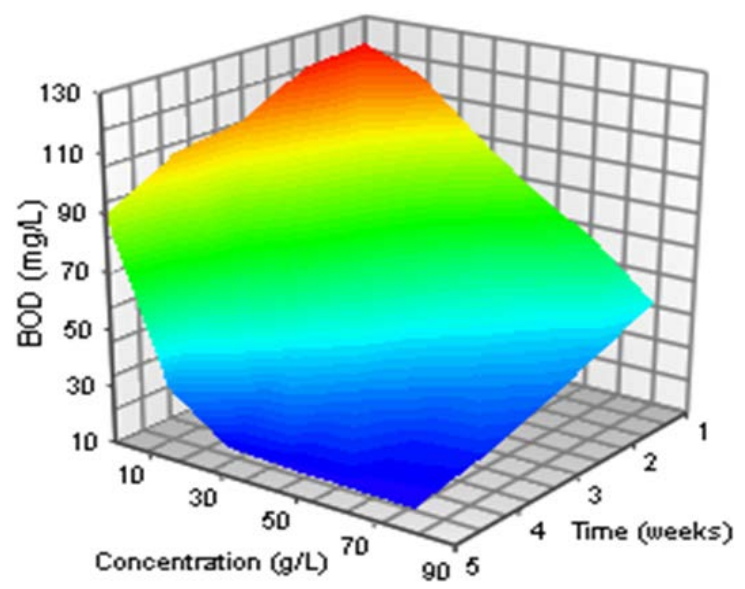

Figure 5. Variation of BOD with time for wastewater remediated with NPK fertilizer

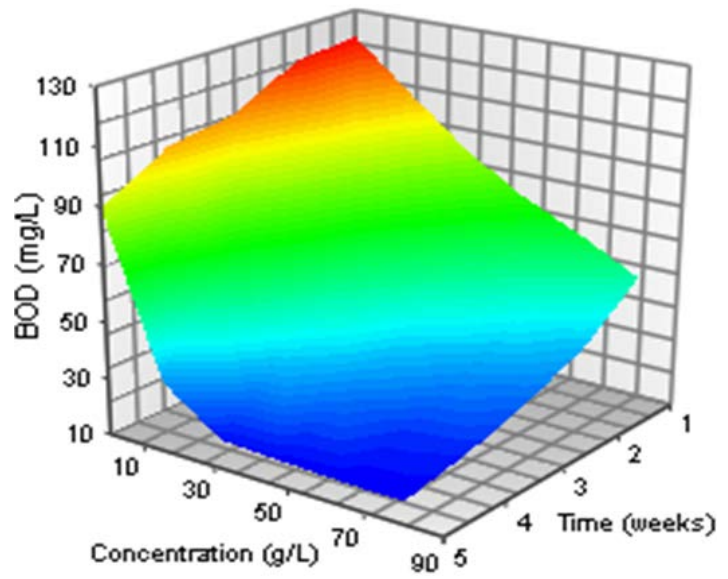

Figure 6. Variation of BOD with time for wastewater remediated with both urea and NPK fertilizer 
The increase in the DO corresponds to the decrease in BOD of the wastewater as indicated in Figure 4, Figure 5 and Figure 6. The BOD directly affects the amount of dissolved oxygen in water bodies. The higher the BOD, the more rapidly oxygen is depleted in the water body. This means that less oxygen is available to aquatic life. The effects of high BOD are the same as those for low dissolved oxygen: aquatic organisms become stressed, suffocate, and die [24]. The increase in DO level is an indication of the occurrence of bioremediation [25].

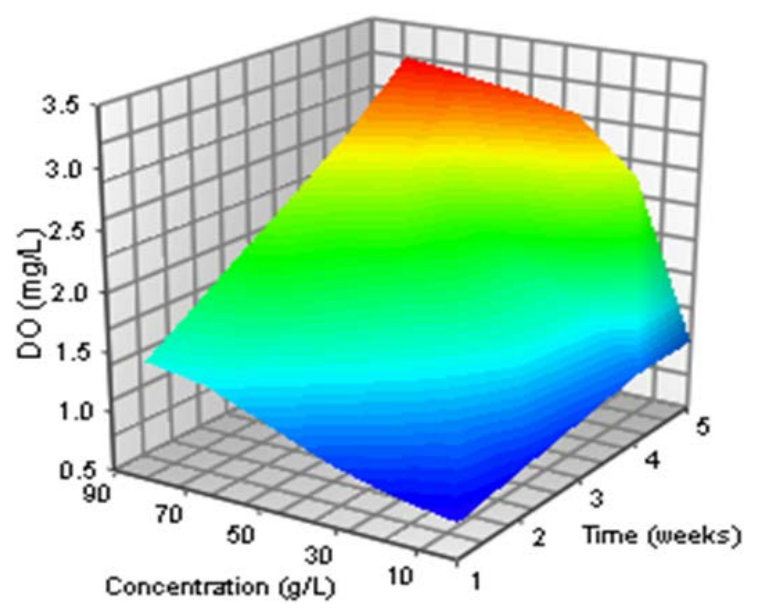

Figure 7. Variation of DO with time for wastewater remediated with urea fertilizer

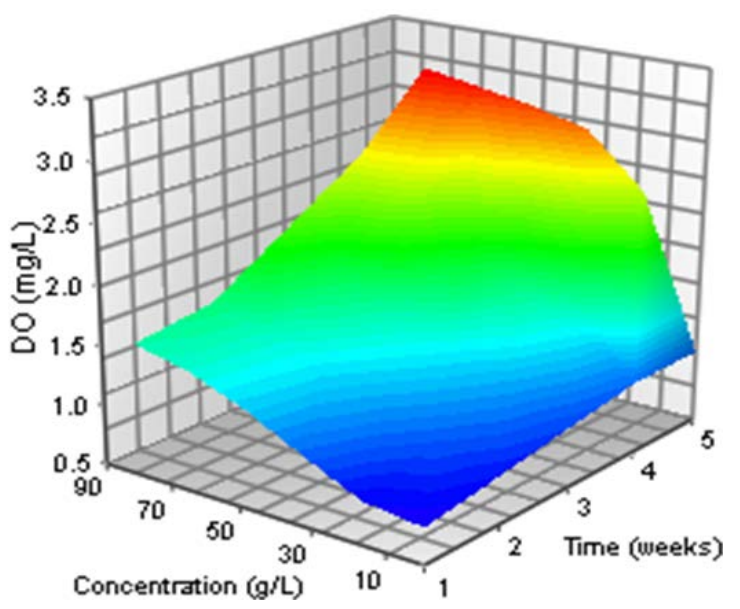

Figure 8. Variation of DOwith time for wastewater remediated with NPK fertilizer

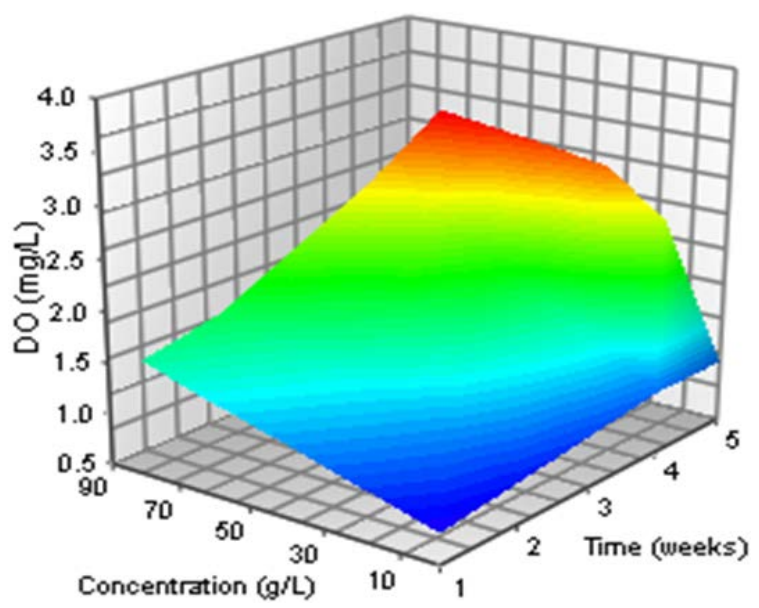

Figure 9. Variation of DO with time for wastewater remediated with both urea and NPK fertilizer
Although the initial DO of the wastewater $(0.8 \mathrm{mg} / \mathrm{L})$ was far below the limit of $2.0 \mathrm{mg} / \mathrm{L}$ set by FEPA, the indigenous microbes upon stimulation by the fertilisers were able to improve DO level to $3.4,3.2$ and $3.6 \mathrm{mg} / \mathrm{L}$ respectively for biostimulation with urea, NPK and a combination of both respectively. These results again show that using a combination of both fertilisers led to the best degradation efficiency of the indigenous microbes when compared with the use of the individual fertilisers.

\section{Conclusions}

The potential use of urea and NPK fertilizers as stimulants of indigenous microbes in the bioremediation of domestic wastewater was investigated in this study. The following conclusions can be drawn.

- The wastewater used for the study contained some indigenous microbes as seen in the decrease in BOD and increase in DO of the wastewater in the absence of nutrient supplementation.

- The use of urea and NPK 15:15:15 fertilisers enhanced the bioremediation capability of the indigenous microbes (typically bacteria such as Bacillus spp, Microccoccus spp, E.coli and fungi such as Aspergillus spp and Penicillium spp) present in the wastewater. This was evident in the significant reductions in BOD as well as increase in the DO of the wastewater in the course of bioremediation.

- Urea and NPK fertilisers are effective in reducing organic matter (decrease in BOD and increase in DO) to acceptable limits.

- Combining the two fertilisers is more effective in remediating domestic wastewater as evident in the results obtained when both urea and NPK were used together.

\section{Acknowledgement}

The authors acknowledge the support of the staff of the department of Chemical Engineering, University of Benin Laboratory.

\section{References}

[1] De-Bashan, L.E, and Bashan, Y, "Immobilized microalgae for removing pollutants: review of practical aspects,” Bioresource Technology, 101, 1611-1627. 2010.

[2] Arora, A. and Saxena, S, "Cultivation of Azolla microphylla biomass on secondary treated Delhi municipal effluents," Biomass Bioenergy, 29, 60-64. 2005.

[3] Gasperi, J., Garnaud, S., Rocher, V. and Moilleron, R, "Priority pollutants in wastewater and combined sewer overflow," Science of the Total Environment, 407, 263-272. 2008.

[4] Morill, J.A., Antizar-Ladislao, B., Monteoliva-Sanchez, M., Ramos-Cormenzana, A. and Russell, N.J, "Bioremediation and biovalorisation of olive-mill wastes," Applied Microbiology and Biotechnology, 82, 25-39. 2009.

[5] Otokunefor, T.V. and Obiukwu, C, "Impact of refinery effluent on the physicochemical properties of a water body in the Niger delta," Applied Ecology and Environmental Research 3, 61-72. 2005.

[6] Godos, I.D., Blanco, S., Garcia-Encina, P.A., Becares, E. and Munoz, R, "Long-term operation of high rate algal ponds for the bioremediation of piggery wastewaters at high loading rates," Bioresource Technology, 100, 4332-4339. 2009. 
[7] Munoz, R. and Guieysse, B, “Algal-bacterial processes for the treatment of hazardous contaminants: a review. Water Research, 40, 2799-815. 2008.

[8] Mulbry, W., Kondrad, S., Pizarro, C. and Kebede-Westhead, E, "Treatment of dairy manure effluent using freshwater algae: algal productivity and recovery of manure nutrients using pilot-scale algal turf scrubbers,” Bioresource Technology, 99, 8137-8142. 2008.

[9] Beg, M.U., Saeed, T. Al-Muzaini, S. Beg, K.R. and Al-Bahloul, M, "Distribution of petroleum hydrocarbon in sediment from coastal area receiving industrial effluents in Kuwait," Ecotoxicology and Environmental Safety, 54, 47-55. 2003.

[10] Otokunefor, T.V and Obiukwu, C, "Efficacy of inorganic nutrients in bioremediation of a refinery effluent,” Scientia Africana, 9(1), 111-125. 2010.

[11] Agarry, S.E., Durojaiye, A.O., and Solomon, B.O. Microbial degradation of phenols: a review. International Journal of Environment and Pollution, 32(1), 12-28. 2008.

[12] Agbor, R.B., Ekpo, I.A., Osuagwu, A.N., Udofia, U.U., Okpako, E.C. and Antai, S.P, "Biostimulation of microbial degradation of crude oil polluted soil using cocoa pod husk and plantain peels,” Journal of Microbiology and Biotechnology Research, 2(3), 464469. 2012.

[13] Obahiagbon, K.O. and Aluyor, E.O, "Comparison of the efficiency of sodium nitrate and sodium nitrite as nutrients in the bioremediation of petroleum hydrocarbon polluted water," Scientific Research and Essay, 4(8), 728-732. 2009.

[14] Kim, S.J. Choi, D.H. Sim, D.S. and Oh, Y.S, "Evaluation of bioremediation effectiveness on crude oil-contaminated sand," Chemosphere 59, 845-852. 2005.

[15] Chikere, C.B., Okpokwasili, G.C. and Chikere, B.O,”Bacteria diversity in a tropical crude oil polluted soil undergoing bioremediation,” African Journal of Biotechnology, 8 (11), 25352540. 2009.

[16] Ebere, J.U., Wokoma, E.C. and Wokocha, C.C, "Enhanced Remediation of a Hydrocarbon Polluted Soil,” Research Journal of Environmental and Earth Sciences, 3(2), 70-74. 2011.
[17] Okoh, I.A, "Biodegradation alternative in the clean up of petroleum hydrocarbon pollutants,” Biotechnology and Molecular Biology Review, 12, 38-50. 2006.

[18] APHA, AWWA, and WPCF. 'Standard Methods for the Examination of Water and Wastewater', 17th edition. American Public Health Association, Washington DC, U.S.A, 2000.

[19] Samal, N.R., Roy, D., Mazumdar, A. and Bose, B. "Seasonal Response of Water Temperature of Rabindra Sarobar, the National Lake, in relation to $\mathrm{pH}$, Dissolved Oxygen, Biochemical Oxygen Demand and Chemical Oxygen Demand”, Journal of the Institution of Public Health Engineers., 2004(2), 39-42. 2004.

[20] Zhao, P., Min, G., Zhang, Y., Yang, Z.Y. and Wang, S, "Comparative Research on Removing Pesticide Residues from Vegetable and Fruit with Different Detergents[J]”. Food Science, 12, 115. 2006.

[21] Federal Environmental Protection Agency (FEPA), Guidelines and 'Standards for Environmental Impact Assessment in Nigeria, 1997, 87-95.

[22] Samal, N.R., Saha, P., Roy, P.K., Biswasroy, M., Venkat Ramana, R., abd Mazumdar, A. "Limnological analysis of an urban polluted lake in Bangalore City in India”. Desalination and Water Treatment, 30(1-3), 217-228. 2011.

[23] Satyawali, Y. and Balakrishnan, M, "Wastewater treatment in molasses-based alcohol distilleries for COD and color removal: a review,” Journal of Environmental Management, 86(3), 481-497. 2008.

[24] Mazumdar, A., Samal, N.R., Roy, D., and Gangopadhyay, A.. "Physico-Chemical Characteristics of Water in a shallow lake Rabindra Sarobar in Metropolis Kolkata”, Journal of the Institution of Public Health Engineers. (IE-CH), India, 88, 32-40. 2007.

[25] Droste, R. L, Theory and practice of water and wastewater treatment, New York etc: Wiley, 1997. 622-629. 